Article

\title{
Francesco Petrarca and the Parameters of Historical Research
}

\section{Ronald Witt}

William B. Hamilton Professor of History (emeritus), Duke University, 129 Carr Building, Campus Box 90719, Durham, NC 27708-0719, USA; E-Mail: rwitt@duke.edu

Received: 25 June 2012; in revised form: 29 July 2012 / Accepted: 31 July 2012 /

Published: 20 August 2012

\begin{abstract}
Although scholars in the first two generations of humanism wrote the histories drawing heavily on ancient Roman sources, Petrarca was the first humanist historian to focuses on the history of ancient Roma. Because he was also the earliest to approach ancient Romans as historically conditioned human beings, he was able to see the achievements of the Romans in historical perspective. At the same time he was unable to separate mythology from history and acknowledged the effect of divine and diabolical forces on the course of human events.
\end{abstract}

Keywords: humanist historiography; historical perspective; Dark Ages; secularization

Scholars of Italian humanism have long recognized that the conception of their movement as constituting the rebirth of ancient culture had a religious origin ultimately traceable to the Christian belief in the rebirth of the sinner in Christ, that is, the recovery of divine acceptance lost for the human race by the fall $[1,2]$. The rebirth that occurred in baptism prefigured the vast majority of medieval reform movements in that in one way or another, the latter aimed at restoring the spiritual purity that had been lost over the centuries. Although Italian humanists of the Renaissance were primarily dedicated to emulating the intellectual, artistic, and moral achievements of the ancient world, both they and medieval reformers used similar terms, renovatio, reformatio, reflorere, to describe their goals, terms that implied in one way or other a certain perspective on history [3,4] The object of all these reform movements was to recover that which over an intervening period of time had been lost.

The humanists, however, differed from medieval reformers in the sharpness with which they saw the past. Medieval reformers looked back for guidance to outstanding exemplars of spirituality like the primitive church, the Apostles, the Egyptian Desert Fathers, or early Benedictine monasticism, but they showed little concern to examine these exemplars as historically conditioned phenomena. The 
Italian humanists too had their exemplars of conduct, the great writers and heroes of ancient pagan Greece and Rome, but at the same time they had a scholarly interest in the ancient world apart from its usefulness to the present. In the long run, the clarity with which they came to grasp the nature of ancient society gave them a sense of historical perspective that led them (1) to an understanding of the past as a time-differentiated series of social, political, religious, and intellectual changes, and (2) against that backdrop, to objectify the present with a view to the reform of contemporary society and politics.

The origin of this appreciation of the past can be found in the work of Francesco Petrarca (1304-1374), who, appalled by the moral corruption of his own society, looked back to ancient Rome as the exemplar of human achievement. As he famously asked: "What else, then, is all history if not the praise of Rome?” ([5], p. 417: “Quid est enim aliud omnis historia, quam Romana laus”). His question would have been met with incomprehension by the two earlier generations of humanists of whom the most outstanding were Lovato de' Lovati (1240-1309) and Albertino Mussato (1261-1329). ${ }^{1}$ While drawing on ancient Roman sources for their own work, Lovato and Mussato showed little interest in investigating the nature of the society that produced them. The poetry of Lovato, the founder of humanism, reveals a confused notion of the ancient past where Greek and Roman history and mythology mingle without distinction as to their basis in reality. Albertino Mussato, Lovato's major disciple, and Mussato's younger Veronese contemporary, Ferreto dei Ferreti (1294-1337), derived their stylistic techniques from ancient Roman historians, primarily from Livy, but the focus of their interest was on contemporary history. ${ }^{2}$

At the same time, the effort of the first two generations of humanists to classicize their Latin through intensive study of ancient vocabulary and phraseology would lead later humanists to an appreciation of the thinking processes of ancient writers and render them approachable as personalities, that is, as historically conditioned human beings.

Besides the historians of modern history at Padua and Verona, a second group of learned historians in the two generations before Petrarca, Riccobaldo of Ferrara (1244/45-ca. 1318), Giovanni Matociis (Mansionarius) (died 1337), Benzo of Alessandria (died. ca. 1330), and two members of the Colonna family, Landolfo (ca. 1250-1331) and Giovanni (ca. 1298-1343/44) were authors of universal narratives of the history of the world. With the exception of Giovanni Matociis' work, these narratives ran from Adam and Eve down to their own day. ${ }^{3}$ In Matociis's case, the author planned to narrate European history from Augustus to Henry VII. The presentation of Roman history by these historians manifested a broad acquaintance with Roman historical writing but they had no interest in imitating ancient Latin style. Their treatment of ancient Rome was presented as part of a continuous flow of events and lost its distinctiveness within a more extended narrative.

The same is true for the version of universal history that took the form of biographies of great men from all ages. Petrarca must have known Giovanni Colonna's De viris illustribus, a series of lives of pagans and Christians arranged chronologically down to modern times, written in Avignon before

1 In [6], I argue that Lovato and Mussato, who are generally considered "prehumanists," are "humanists," and that "prehumanism," a term that has never been defined clearly, really means "pre-Petrarcaan," pp. 19-21.

2 Mussato's most important historical writing was entitled De gestis Henrici septimi Cesaris and was initially published in [7]. Ferreto's major historical work, Historia rerum in Italia gestarum, was edited by Carlo Cipolla, [8].

3 See my discussion of these historians in [6], pp. 112-14, 166-68, and 282-84; on Giovanni Matociis's Historiae imperiales, see [9]. Only the period between Augustus and Charlemagne was completed. 
Colonna's departure for Rome in 1338 [10]. Another friend of Petrarca, Guglielmo Pastrengo (1290-1352), who visited Avignon the year after Giovanni's departure, may well have seen a copy of Giovanni's work before composing his own De viris illustribus and De originibus [11]. Both of these works, like Giovanni's, contained biographies of famous pagan and Christian heroes and authors.

With the exception of Benzo of Alexander, historians in both universalistic traditions shared a common conception of the ancient texts. The writings of the pagan authors were sacred: contradictions in the texts were only apparent and had to be reconciled. Whereas historians of modern history like Mussato and Ferreto had to determine what the facts were and order them in their account of recent events, these historians accepted the ancient past as given. If direct contact with the ancient past was to be established, the ancient historians had to be confronted, interrogated, and their writings reworked by the historical imagination.

Benzo of Alexandria (d. 1337) made a beginning of this process in his Cronica a mundi principio usque ad tempora Henrici ([12], 2, pp. 134-136). Despite his Cronica's medieval Latin diction and its encyclopedic approach, Benzo developed rigorous techniques in textual criticism. He endeavored to find the most reliable witnesses for his account and when they contradicted one another, he discussed the disagreements and then chose the most likely position. He also entertained the possibility that some of the contradictions were conscious distortions on the part of the writers. He did not hesitate to compare readings from different manuscripts and to admit obscurity in his sources when he found it. Benzo's Cronica, however, blended the history of ancient Rome into a history that ran from Adam down to the fourteenth century.

Nevertheless, Petrarca's focus on ancient Rome was not without precedent. Although he denied any influence of Dante on his work, it is more than likely that Petrarca's historical orientation had been affected by Dante's insistence that ancient Rome had been both the center of a perfect secular society and the site where Peter established Christ's church. ${ }^{4}$ Moreover, although Dante's great poem represents a lyricization of universal history, the poet's imaginative recreation of ancient and modern personalities as interlocutors may also have inspired Petrarca. Despite the secular character of Petrarca's approach and his pessimism in later life regarding the possibility of Dante's hoped-for restoration of the empire at Rome, nothing earlier in Western literature comes closer to Petrarca's conversations with his correspondents than Dante's poetic re-creation of men of antiquity in the Commedia.

At the very least Dante's emphasis on Rome would have resonated with the young Petrarca, who from the age of eight grew up in the area of Avignon, the ecclesiastical capital of Europe. Member of a refugee Florentine family, living in a milieu of papal bureaucrats largely Italian, but employed by a clerical hierarchy dominated by Frenchmen, Petrarca likely heard as a boy his father lament the

4 Referring to the place of the Roman empire in Dante's poem, Peter Armour, ([13], p. 170), writes: "What Dante is seeing is, in the first place, the mystery of the twofold providentiality of Augustus' perfect earthly Monarchy which prepared for Christ and thus of the ideal which, though its paganism was superseded, was thereby transmitted into the history of mankind redeemed by Christ and to the Christian world." Although there is no proof that Petrarca read Dante as a young man, he himself acknowledges in a letter to Boccaccio in 1359 that in his youth Dante's writings were easily available to him in Avignon (sine difficultate parabili). Defending himself to Boccaccio, who had sent him a copy of Dante's writings, he writes that although eager to collect books as a youth, he did not want to be influenced by the poet in his own vernacular work. In this way he sidestepped the question as to whether or not he had read Dante ([14], 4, p. 96). 
desolation of Rome and the humiliation of Italy. Boasts of French superiority only sharpened his loyalty to his land of origin and to its Roman heritage.

Petrarca had longed for years to see Rome and when he finally did in the spring of 1337, the remains of the great ancient metropolis exceeded his expectations. As he wrote to his patron, Cardinal Giovanni Colonna, just after his arrival in the city, seeing Rome in ruins did not diminish his opinion of the city's greatness, but increased it:

"In truth, Rome was greater, and greater are its ruins than I imagined. I no longer wonder that the whole world was conquered by this city but that it was conquered so late." 5

Against the background of this experience, Petrarca's belief that the history of ancient Rome was the only history worth knowing makes sense.

Loathing his own time, he tells us in his autobiography written in the last years of his life,

"I especially dedicated myself to learning about antiquity, inasmuch as I have always disliked my own age, so that, had I not been restrained by the love of dear ones, I would always have wanted to be born in any other age. In order to forget my own time, I have always tried to place myself in spirit in other times. Therefore I took pleasure in history."

His status as exile belonging nowhere in space might have facilitated the liberation of his imagination from his own time that he speaks of here.

Petrarca's sense of the historicity of the ancient Roman past, however, developed largely out of his humanist inheritance. His dedication to close study and imitation of ancient style, especially advanced by his youthful editions of Virgil and Livy, disclosed not only the literary techniques of ancient artistry, but the very processes of thought of the great writers. Such a degree of familiarity with the ancients awakened Petrarca to the fact that these writers were men of extraordinary talent but still men, creatures of history and proper subjects of historical research.

He granted, as he wrote, that although cities and kingdoms fall, kingdoms are transferred, customs vary, and laws are altered,

"those things which are truly innate by nature do not change, and the minds of men and the diseases of minds are really the same as they were when Plautus imagined them."”

5 "Illa vero, mirum dictu, nichil imminuit, sed auxit omnia. Vere maior fuit Roma, maioresque sunt reliquie quam rebar. Iam non orbem ab hac urbe domitum, sed tam sero domitum miror" ([14], 1, p. 81). Unless specified all English translations are mine.

6 "Incubi unice, inter multa, ad notitiam vetustatis, quoniam michi semper etas ista displicuit; ut, nisi me amor carorum in diversum traheret, qualibet etate natus esse semper optaverim, et hanc oblivisci, nisus animo me aliis semper inserere. Historicis itaque delectatus sum... ([15], p. 6).

7 "Que vero naturaliter insunt, non mutari, et animos hominum et animorum morbos prope omnes eosdem esse, qui fuerint, dum Plautus ista fingebat" ([14], 2, pp. 27-28). Petrarca had just cited several moralisms of Plautus. Also note: "Mundus idem est qui fuit; item sol, eadem elementa; virtus sola decrevit; civitatum nempe manuque congestarum molium alie creverunt, decrevere alie, quedam funditus corruerunt, nostris quedam surrexere temporibus: vetus est vicissitudo rerum humanarum" ([14], 3, p. 267). The later passage is cited from [16], pp. 404-05. In his important article summarizing Petrarca's political attitudes, Michele Feo, without citing these quotations, illustrates Petrarca's idea of the unchanging nature of human beings over time through examples from the humanist's actions ([17], pp. 116-18). 
The result was a desacralization of ancient time and grasp of the great men of antiquity as human beings. Because of the basic constancy of human nature, not only are the moral teaching of ancient writers still valid, but the great men of antiquity can also serve as models of moral conduct and achievement for those of Petrarca's age.

The consequences of this desacralization were twofold. First of all, in contrast with the Christian apologetic tradition represented by Dante and earlier humanists like Mussato who maintained that pagan poets such as Virgil and Ovid wrote at points under divine influence, Petrarca steadfastly affirmed that what was taken as prophesy in their work was the product of their natural genius and that the truths they revealed were reached by natural reason ([18], pp. 540-44).

Second, his view of the great ancient writers as historically determined beings also affected his attitude toward the authority of their work. Ancient history was not frozen in the texts. Petrarca recognized that ancient historians like modern ones were liable to error and prejudice. Because of the contingent character of the texts, therefore, they were accessible to the critical judgment of the modern historian intent on constructing his own version of the past. Benzo of Alexandria, whom Petrarca had perhaps read, may have played the pioneering role in the development of textual criticism, but little in his works suggests that he viewed the ancients as personalities.

The intimacy which Petrarca felt for the great men of antiquity is perhaps best illustrated in his Letters to Famous Men in which he often pronounces judgments on the lives and works of his long-dead correspondents. In a number of cases he makes a point of demonstrating the temporal distance between himself and them. As he concludes his letter to Cicero:

"From the land of the living, on the right bank of the Adige, in the city of Verona, in transpadane Italy, on 16 June in the year 1345 from the birth of that God whom you did not know."

In these letters to the ancients Petrarca uses his scholarship to construct imaginatively their historical epoch, and by implication articulate the temporal and cultural gap that separates them from his own time. Indeed, it is this sense of historical distance that constitutes the basis of our modern sense of anachronism, the sense of the historically inappropriate that seems to us in the contemporary world as simply part of our mental equipment, but that in fact was one of the great contributions of the humanists to modern thought.

For example, Petrarca's account of the murder of Caesar from his De gestis Cesaris (post 1366), essentially based on Suetonius, takes the form of a dialogue with the ancient historian. Petrarca is quick to condemn those among the assassins who had benefitted from Caesar's generosity. Of the omens presaging Caesar's coming death, he suggests that the finding of a stone in Capua predicting the assassination, which Suetonius considers a fact, may only be a legend. As for the other omens, even though at that time people believed in them and conducted themselves accordingly, Caesar as a cultivated and magnanimous person was right to overlook them. ${ }^{9}$ The dictator should, however, have

8 "Apud superos, ad dextram Athesis ripam, in civitate Verona Transpadene Italie, xvi kalendas Quintiles, anno de ortu Dei illius quem tu non noveras" ([14], 4, p. 227).

9 Coniuratum est in eum a sexaginta sentoribus, Gaio Cassio et Marco ac Decimo Brutis tante cedis ducibus, quórum primus atque ultimus e suorum numero erant, medius semper adverse partis extiterat sed, venia donatus ac provincia auctus, aut oblata respuere aut profecto ipse quoque suus esse debuerat...Potest enim ese res fabulosa, quamvis eam Suetonius Tranquillis affirmet...Omitto suum et uxoris sue somnium, et que sunt id genus omnia, que a viro tam docto, 
known what to expect, because the rumor of his coming assassination was public knowledge. His failure to read the note warning him of the plot that was handed him as he was going into the curia has led rulers since to read immediately what is handed them ([19], p. 316). The sense of temporal distance emerging from these passages prevades the De viris.

At its widest Petrarca's historical vision of ancient Rome embraced the centuries from the foundation of the city to the centuries of its decadence or, to use the phrase of Theodore Mommsen, to the beginning of the 'Dark Ages'. ${ }^{10}$ Although he frequently identifies two periods of history, ancient and modern, without defining the point of demarcation between them, in Africa, his epic poem probably begun in 1338 and celebrating the victories of Scipio Africanus, Petrarca has Scipio break off his prophesy of the future with the reigns of Vespasian and Titus because "I cannot bear to proceed: for strangers of Spanish and African extraction will steal the sceptre and the glory of the Empire founded by us with great effort." ${ }^{11}$ The earliest edition of his work of historical biography, De viris illustibus, written in the 1340s, however, includes biographies of Roman leaders from Romulus to Titus (d. 81 C.E.), who was born in Spain, while the projected reworking of the text at the end of his life was to begin with Romulus and end with Trajan (d. 117 C.E.), another emperor of Spanish origin.

Consequently, at the latest, the great age of Rome ended for Petrarca in the early second century A.D. and thereafter began the age of shadows (tenebrae) which presumably endured down to

tam magnanimo, iure optimo, ni fallor, sperni poterant; sed tunc vulgo observari talia, imo et procurari accuratius et caveri mos erat. Illud certe sapientissimo duci oculos aperuisse debuerat, quod et fama cedis in vulgus effusa erat..." ([19], pp. 315-16).

10 This term is taken from the well-known article of Petrarca's conception of ancient Roman history by Mommsen, [20].

11 "Ulterius transire piget; nam sceptra decusque/ Imperii tanto nobis fundata labore/ Externi rapient Hispane stirpis et Afro" ([21], p. 40 cited from [20], p. 119). For a criticism of Mommsen's position that Petrarca envisaged the early second century C.E. as the beginning of the "dark ages" and of the secular character of Petrarca's conception of Roman history, see [22]. Black cites numerous passages in Petrarca's writings that criticize the Donation of Constantine as destroying the primitive church and introducing corruption into the institution. As Black interprets Petrarca, the Donation of Constantine constituted the end of antiquity ([22], p. 66). Crucial to his disagreement with Mommsen is a letter of Petrarca to Giovanni Colonna, ostensibly written in 1337, describing a walk together through the ruins of Rome and listing ancient pagan sites that they have seen followed by a number of Christian sites ([14], 2, pp. 55-60). He cites Petrarca's word: "Multus de historiciis sermo erat, quas ita partiti videbamur, ut in novis tu, in antiquis ego viderer expertior, et dicantur antique quecunque ante celebratum Rome et veneratum romanis principibus Christi nomen, nove autem ex illo usque ad hanc etatem...([14], 2, p. 58). In an effort to give substance to this vaguely phrased division into ancient and modern times, Black adds: "This scheme is reinforced by his archaeological picture of ancient Rome: this is presented not in topographical but in chronological order-first of the classical, then of Christian sites: his account goes up to Sylvester and Constantine and then abruptly breaks off" ([22], p. 66). The passage to which Black refers is the following: "Hic Christus profugo vicario fuit obvius; hic Petrus in crucem actus; hic truncatus est Paulus; hic assatus Laurentius; hic sepultus venienti Stephano locum fecit. Hic sprevit fervens oleum Johannes; hic Agnes post obitum vivens suos flere prohibuit; hic Silvester latuit; hic lepram deposuit Constantinus; hic gloriosam Calixtus exercuit Libitinam" ([14], 2, p. 58). The series of references, however, are not in fact in chronological order. John the Evangelist (d. ca. 100) is inserted between Lawrence, burned in 258, and Agnes, martyred in ca. 304. Contrary to Black's assertion, the list does not "go up to Sylvester and Constantine" but it ends with Calixtus, executed in 222. Accordingly, whether Petrarca intended this list as representative of the tour that he and Giovanni took through Rome or whether he recalled these sites as they came to mind, Black is in error in asserting that the list is chronological and that it proves that for Petrarca antiquity ended not as Mommsen has shown in the second century C.E., but with Constantine. 
Petrarca's generation. Responding to Agapito Colonna, who was angry when he heard that he was not to be included in the De viris illustribus, Petrarca responded:

"I am unwilling to carry my treatment to such a distance and through so many shadows (tenebrae) for so few famous men; for this reason sparing material and labor, I set and determined the limit of my history long before our century" ([14], 4, pp. 28-29)

To his misfortune Petrarca had been born too late or too soon. As he wrote in his Rerum memorandarum libri:

“... I, with so many reasons to lament, have none to console me, placed as I am at the boundary line between two peoples and looking, at the same time, behind and ahead." $" 12$

Nevertheless, although the contribution of Petrarca to the development of the concept of historical perspective is undeniable, much in his writing reflects the confusion of myth and history that characterized ancient and medieval historiography. In 1890, Pierre de Nolhac announced his discovery of a new manuscript of Petrarca's De viris illustribus that differed significantly from manuscripts of the work then known in that it began with a long preface followed by twelve vitae of biblical and mythological figures from Adam to Hercules [24,25]. Nolhac and later scholars down to the 1940s assumed that the text was the earliest version of the work and that subsequently Petrarca had excised the first twelve as his vision of the ancient past evolved. ${ }^{13}$

On the contrary, recent scholarship has established that the text beginning with non-Roman biographies was written in 1351 or 1352 , several years after the first edition that began with Romulus. ${ }^{14}$ It probably reflects Petrarca's intention to expand his treatment of ancient biographies beyond the Roman ones. There is evidence, moreover, that for a period of years in the 1350s, prior to the letter to Agapito Colonna cited above, he had contemplated an "all-ages" or a universal version of De viris illustribus that included modern heroes ([28], pp. 224-25).

Each of the twelve lives of the second edition rests on the assumption that the hero was a historical being. In the case of the biblical figures, Petrarca has Scripture and the early Church Fathers as his evidence. As for the mythological figures Petrarca relies with confidence on pagan as well as early Christian sources. In the case of Hercules, for example, he begins by admitting that Varro maintained that many men in previous times had been called Hercules because of their immense strength. Nonetheless, Petrarca seeks to establish the life of the one real Hercules "by depending on the more reliable but rare traces of what has been handed down." 15

12 "Ego itaque, cui nec dolendi ratio deest nec ignorantie solamen adest, velut in confinio duorum populorum constitutus ac simul ante retroque prospiciens..." ([23], 1, p. 19).

13 On the chronology of Petrarca's composition of the De viris illustribus, see [26] and [27]. The earliest version of the De viris illustribus included three foreigners among the twenty-three lives, Hannibal, Pyrrhus, and Alexander.

14 Martellotti considers this second version the initial portion of an "all-ages" version of De viris illustribus, which Petrarca never completed ([26], p. 51). According to my reading of the preface to the twelve lives, however, Petrarca still intended to limit the work to ancient heroes, not to heroes of all periods ([27], pp. 107-8). The preface specifically refers to the pagan religious beliefs of his heroes: "multa etiam sciens apud alios ystoricos interserta vel vetusti moris vel insulse religionis, dicam melius superstitionis, plus tedii quam utilitatis aut voluptatis habitura preterii ...” ([25], p. 24).

15 "Id causa est quod de Hercule tam incerta, tam varia scripta sint ut velut laberinthi ambagibus implicitus lector exitum non inveniat. Sane quantum ingenii funiculo datum erit, inter caliginosas vetustissime rei semitas, vitatis multiplicium 
Conflicting sources considered Hercules to have been either a philosopher or a man of superhuman strength, but the examples of other exceptional men bear witness to the fact that intellectual and physical gifts can be combined in the same person. Among the labors that Petrarca believed the historical Hercules actually performed are his conflict with the Amazons, the Centaurs, Antaeus, and the Hydra. That Hercules supported the heavens on his shoulders, however, appears to Petrarca as an allegorical reference to Hercules's astronomical knowledge, while feats such as the leveling of mountains, the descent into hell, and the chaining of the beast with three heads "I pass over as fabulous." $" 16$

The ascription of superhuman qualities to figures like Jason and Hercules, whom we now consider mythological, challenges Petrarca's own principle of the continuity of human nature that is the foundational principle of his concept of historical perspective. The historical existence of creatures such as the Hydra and the centaurs, moreover, implies a contradiction to the general constancy of nature that underlies his position on human nature.

The potentialities of human activity within his space-time coordinates are further conditioned by divine and demonic intervention. Although omnipresent to human history, God and the Devil seem to have been especially active in ancient times. By means of Noah, Abraham, Jacob, Joseph and Moses, God worked in history toward the time appointed for Christ's birth. While using their natural reason, ancient poets may have written certain truths about the divine, but Petrarca does not hesitate to assert that God directly inspired the Erithrean or Cumean Sybil to prophesy Christ's coming ([31], p. 40). Again, despite Petrarca's conception of the creation of the Roman empire as a human achievement, he cannot resist associating the empire with the birth of Christ. While leaving the causal relationship ambiguous, he writes: “.... at what better time did God, the lover of peace and justice, deign to be born of the Virgin and visit the earth?"([31], p. 175: "Quo potissimum tempore amator pacis ac iustitie nasci deus ex virgine terrasque visitare dignatus es?")

As for demons, the pagan religion began when these evil beings took possession of statues erected by grieving relatives for their dead family members. However, although the demons fled the idols at the coming of Christ, demons remain an active source of historical causation in that they continue to tempt the human race to sinful actions ([30], p. 34). ${ }^{17}$

Finally, Petrarca's secular interpretation of ancient Roman history as demonstrating the height of human achievement made it impossible for him to extend his perspective to succeeding centuries. He never doubted that the advent of Christ marked the beginning of the era of revealed truth, one that

perplexitatibus errorum, per certiora tradentium, licet rara, vestigia ad verum quam propinquius licebit accedam" ([25], p. 104). Martellottti stresses that in writing these twelve lives Petrarca has drawn exhaustively on pagan and Christian writers for his information. For the vita of Hercules, see Caterina Malta's notes, [25], pp. 104-9, and those of Dotti [29], pp. 647-49. Martellotti concludes regarding the twelve lives: "Lungi dal rappresentare una sopravvivenza del Medioevo, anche quest'opera del Petrarca nasce dai suoi libri ed è una conquista del suo umanesimo..." ([26], pp. 79-80).

16 "Thesalie fauces et scissa iuga monitum, et emissi amnes, ut fractum Acheloi cornu et copie dedicatum, ut descensum ad inferos et iecta trifauci monstro vincula, et cetera, quorum longa narratio est, fabulosa pretervehar" ([25], p. 108).

17 But, Petrarca warns his contemporaries that there are "milia tentationum et demonum insidie immortales et permissu omnipotentis Dei violenti spirituum incursus et tam multa sine indutiis animarum bella domestica ...” ([30], p. 36). For the origin of pagan gods (as demons possessing statues), see [30], pp. 42 and 44, as well as p. 22: "All gods of the nations are demons." 
exposed the utter falsity of pagan belief. Throughout his work the ascetic theme that "nothing endures" served as a counterpoint to his enthusiasm for ancient culture. In the face of the eternal, all worldly achievement became worthless, and the secular glory pursued by his ancient heroes would seem to have counted least of all. Insistence on the Roman achievement, consequently, had to be sealed off from any comparison with early Christianity. Otherwise, he would have had to view Jerome and his beloved Augustine as participants in a world in decline. To avoid this, perhaps unconsciously, his writings place the Latin Church Fathers in a vague spatio-temporal context without continuity with the ancient Roman past.

Of course, to criticize Petrarca because he was not a modern historian is unfair. It would be too much to expect him to have rejected pagan and Christian traditions that accepted as historical beings, figures whom we today consider mythological. Nor should we be surprised that among his sources of historical causation he recognized occasional interventions of God and the Devil, a view still held as the basis of historical explanation by some today. The goal of this paper has rather been to credit Petrarca with a pioneering role in developing a concept of historical perspective while at the same time qualifying the extent of his modernity by situating his innovative conceptions within his complex vision of the past with its strong allegiances to his predecessors.

\section{References}

1. Karl Burdach. "Sinn_und Ursprung der Worte Renaissance und Reformation." In Sitzberichte der königlichen preussischen Akademie der Wissenschaft. Berlin: Berliner Akademic, 1910, 594-646.

2. Rudolf Hildebrand. "Zu sogenannten Renaissance.” Beiträge zum deutschen Unterricht. Leipzig: B.G. Teubner, 1897, 284-89.

3. Giles Constable. "Renewal and Reform in Religious Life. Concepts and Realities." In Renaissance and Renewal in the Twelfth Century, edited by Giles Constable, and Robert L. Benson with Carol D. Lanham. Cambridge, MA: Harvard University Press, 1982, 37-67.

4. Gerhart B. Ladner. "Terms and Ideas of Renewal." In Renaissance and Renewal in the Twelfth Century, Giles Constable, and Robert L. Benson with Carol D. Lanham. Cambridge, MA: Harvard University Press, 1982, 1-33.

5. Francesco Petrarca. Invectiva contra eum qui maledixit Italie. Edited and translated by David Marsh. Cambridge, MA: Harvard University Press, 2003.

6. Ronald Witt. "In the footsteps of the Ancients." The Origins of Humanism from Lovato to Bruni. Leiden: Brill, 2003.

7. Albertino Mussato. De gestis Henrici septimi Cesaris. Historia augusta Henrici VII Caesaris et alia quae extant opera. Edited by Lorenzo Pignori et alii. Venice, 1636. Separately paginated. Republished by Lodovico Muratori. Rerum italicarum scriptores. Milan, 1727, vol. 10, 27-568.

8. Ferreto de' Ferreti. Historia rerum in Italia gestarum. Edited by Carlo Cipolla. Le opere di Ferreto de' Ferreti vicentino, Fonti per la storia d'Italia. Rome: Forzaní, 1908-10, 3 vols.

9. G. Botari. "Giovanni Mansionario nella cultura Veronese del Trecento." In Petrarca, Verona e l'Europa. Atti del convegno internazionale di studi (Verona, 19-23 sett. 1991), edited by Giuseppe Billanovich and Giuseppe Frasso, Studi sul Petrarca, no. 26. Padua: Antenore, 1997, $21-68$. 
10. Braxton W. Ross. "Giovanni Colonna, Historian at Avignon.” Speculum 45 (1970): 533-63.

11. Guglielmo Pastrengo. De viris illustribus et de originibus. Edited by G. Bottari. Padua: Antenori, 1991, Studi sul Petrarca, 21.

12. Remigio Sabbadini. Le scoperte dei codici latini e greci ne'secoli XIV e XV. Florence: Sansoní, 1905-14, 2 vols.

13. Peter Armour. Dante's Griffin and the History of the World. A Study of the Earthly Paradise (Purgatorio, cantos xxix-xxxiii). Oxford, UK: Oxford University Press, 1989.

14. Francesco Petrarca. Le familiari. Vol. 1-3 edited by Vittorio Rossi, and vol. 4 edited by Vittorio Rossi, and Umberto Bosco. Edizione nazionale di Petrarca. Rome: Sansoní, 1933-42.

15. Francesco Petrarca. Posteritati. In Francesco Petrarca, Prose, edited by Pier G. Ricci, and Guido Martellotti et alii. Milan and Naples: Ricciardí, 1955.

16. Franco Simone. "Il Petrarca e la sua concezione ciclica della storia." In Arte e storia. Studi in onore di Leonello Vincenti. Turin: Giappichelli, 1965, 387-428.

17. Michele Feo. "Politicità del Petrarca." In Il Petrarca latino e le origini dell'umanesimo: Atti del convegno internazionale, Firenze, 19-22 maggio, 1991. Quaderni petrarcheschi 9-10 (1992-93): 115-28.

18. Ronald Witt. "Coluccio Salutati and the Conception of the Poeta theologus in the Fourteenth Century." Renaissance Quarterly 30 (1977): 538-63.

19. Francesco Petrarca. De gestis Cesaris. Edited by Giuliana Crevatin. Pisa: Scuola normale superiore, 2003.

20. Theodore Mommsen. "Petrarch's Conception of the 'Dark Ages'." Speculum 17 (1942): 226-42. Reprinted in Medieval and Renaissance Studies, edited by Eugene F. Rice, Jr. Ithaca, NY: Cornell University Press, 1959, 106-29.

21. Francesco Petrarca. Africa. Edited by Nicola Festa. Florence: Edizione nazionale delle opere di Francesco Petrarca, 1926, vol. 1.

22. Robert Black. "The Donation of Constantine: A New Source for the Concept of the Renaissance." In Languages and Images of Renaissance Italy, edited by Alison Brown, Oxford, UK: Oxford University Press, 1995, 51-85.

23. Francesco Petrarca. Rerum memorandarum libri. Edited by Giuseppe Billanovich. Florence: Edizione nazionale delle opere di Francesco Petrarca, 1945, vol. 5.

24. Pierre de Nolhac. "Le De viris illustribus de Pétrarque. Notices sur les manuscrits originaux suivis de fragments inédits." Notices et extraits des manuscrits de la Bibliothèque nationale et autres bibliothéque 34 (1891): 61-148.

25. Francesco Petrarca. De viris illustribus. II: Adam-Hercules. Edited and translated by Caterina Malta. VII Centenario della Nascita di Francesco Petrarca (2004). Florence: Le Lettere, 2007.

26. Guido Martellotti. "Linee di sviluppo dell'umanesimo petrarchescho." Studi petrarcheschi 2 (1949), 51-80; reprinted in Martellotti, Scritti petrarcheschi, edited by Michele Feo, and Silvia Rizzo. Padua: Antenore, 1983, 110-40.

27. Ronald Witt. "The Rebirth of the Romans as Models of Character." In Petrarch. A Critical Guide to the Complete Works, edited by Victoria Kirkham and Armando Maggi. Chicago and London: University of Chicago Press, 2009, 103-11, 375-84. 
28. Ronald Witt. "La concezione della storia in Petrarca." In Petrarca: Canoni, esemplarita, edited by Valeria Finucci. Rome: Bulzoní, 2006, 211-28.

29. Francesco Petrarca. Gli uomini illustri. Vita di Giulio Cesare. Edited by Ugo Dotti. Turin: Einaudi, 2007.

30. Francesco Petrarca. Il "De otio religioso" di Francesco Petrarca. Edited by Giuseppe Rotondi, Studi e testi, 195. Rome: Biblioteca Apostolic Vaticana, 1958.

31. Francesco Petrarca. "Buch ohne Namen” und die päpstliche Curia. Edited by Paul Piur. Halle an der Saale: Niemeyer, 1925.

(C) 2012 by the author; licensee MDPI, Basel, Switzerland. This article is an open access article distributed under the terms and conditions of the Creative Commons Attribution license (http://creativecommons.org/licenses/by/3.0/). 